\title{
RISIKO RANTAI PASOK MINUMAN SARI APEL DALAM PERSPEKTIF SISTEM TRACEABILITY
}

\author{
Dwi Iryaning Handayani \\ Jurusan Teknik Industri Fakultas Teknik \\ Universitas Panca Marga Probolinggo \\ Jalan Yos Sudarso 107 Pabean Dringu Probolinggo 67271 \\ dwiiryaninghandayani@yahoo.co.id
}

\begin{abstract}
Abstrak
Risiko merupakan faktor-faktor yang menghambat operasional pada rantai pasok makanan yang tidak dapat dihindari akan tetapi dapat diminimalisir atau dihilangkan dengan melakukan penanganan risiko yang tepat. Salah satu penanganan risiko dengan menggunakan sistem traceability. Oleh karena itu penelitian ini bertujuan untuk melakukan penaksiran risiko yang terjadi pada rantai pasok minuman sari apel berdasarkan informasi sistem traceability. Dalam penelitian ini menggunakan metode SCOR (Supply Chain Operation Reference). Sedangkan penilaian risiko rantai pasok menggunakan teknik FMEA (Failure Mode and Effects Analysis). Upaya yang dilakukan dalam mengetahui risiko yang dapat ditangani dengan sistem traceability menggunakan metode House of Risk (HOR). Terdapat 1 risiko ekstrime yaitu risiko terjadinya kekurangan barang dan bahan baku digudang. Sedangkan risiko sedang sebanyak lima. Risiko yang berkatagori rendah sejumlah tujuh. Risiko yang terjadi disebabkan tidak ada prosedur yang jelas, kurang memperhatikan prosedur penyimpanan, inspeksi dilakukan di akhir proses dan kesalahan komposisi bahan baku, Sedangkan penyebab risiko yang bisa ditangani dengan traceability sebanyak $75 \%$ dari semua penyebab risiko yang terjadi. Hal ini menunjukkan bahwa peran traceability pada rantai pasok makanan dapat mereduksi risiko yang terjadi.
\end{abstract}

Kata kunci: risiko, traceability, rantai pasok

\begin{abstract}
Risks are factors that hinder operations in the food supply chain that can not be avoided but can be minimized or eliminated by appropriate risk management. One risk management using a traceability system. Therefore, this study aims to conduct a risk assessment that occurs in apple juice supply chain traceability system based on information. In this study using the SCOR (Supply Chain Operations Reference). While supply chain risk assessment using the technique of FMEA ( Failure Mode and Effects Analysis). Efforts are made to know the risks that can be addressed by using the method of traceability system House of Risk (HOR ). There is one risk is the risk ekstrime shortages of goods and raw materials warehouse. While the risk was as much as five. Risks are categorized as low a number seven. Risks that occur due to no clear procedure, lack of attention to storage procedures, inspections carried out at the end of the process and raw material composition error, while the cause of the risks that could be dealt with traceability as much as $75 \%$ of all causes of the risk. This suggests that the role of traceability in the food supply chain can reduce the risk.
\end{abstract}

Keywords: risk, traceability, supply chain, traceability

\section{PENDAHULUAN}

Setiap aktivitas yang dilakukan oleh perusahaan tidak akan terlepas dari ketidakpastian atau kejadian peristiwa tak terencana yang bisa mempengaruhi aliran bahan dan komponen pada rantai pasok (Svensson, 2000). Ketidak pastian dan dampak dari suatu peristiwa didalam rantai pasok dapat dikatakan dengan risiko
(Sinha,2004). Risiko ini merupakan faktorfaktor yang menghambat operasional pada rantai pasok makanan, yang mana risiko pada rantai pasok dapat terjadi mulai dari hulu pemasok, pabrik, distribusi, dan sampai hilir distributor, konsumen. Risiko lebih dikaitkan dengan kerugian yang diakibatkan oleh kejadian yang mungkin terjadi dalam waktu tertentu (Jutner, 2003). Risiko tidak dapat 
dihindari akan tetapi dapat diminimalisir atau dihilangkan dengan melakukan penanganan risiko yang tepat. Biasanya, satu penyebab risiko dapat merangsang lebih dari satu kejadian risiko(Pujawan et al, 2009).

Terjadinya risiko dapat mengakibatkan kerugian yaitu sebuah konsekuensi negatif yang tidak diinginkan dan ketidak pastian. Salah satu jenis risiko yang terjadi pada produk makanan pada tahun 2007 terjadi 47 kasus penolakan oleh Jepang dan pada tahun 2008 sebanyak 13 kasus umumnya disebabkan oleh cemaran bakteri. Oleh karena itu Uni Eropa mewajibkan semua pelaku usaha bidang pangan di setiap negara dan para pengekspor dari negara lain menggunakan sistem traceability untuk mencatat perjalanan pangan mulai dari pemasok sampai konsumen. Peran pemerintah dalam menjamin keamanan pangan mengeluarkan kebijakan yang berupa PERMENKP RI Nomor: Per. 01/Men/2007 tentang pengendalian sistem jaminan mutu dan keamanan pangan. Pasal 13 berisi tentang prinsip ketelusuran (traceability) yang menekankan bahwa pelaku usaha pengolahan harus memberikan label atau informasi yang mengidentifikasi traceability sesuai dengan persyaratan jenis produk tertentu. Banyak peneliti meyakini bahwa sistem traceability yang dimiliki perusahaan dapat memberikan manfaat terhadap pengelolaan dan pengurangan risiko, hal ini sesuai dengan beberapa pernyataan peneliti yang berkenaan dengan manfaat traceability. Menurut Kher et al. (2010) traceability bermanfaat dalam menemukan sumber-sumber yang berpotensi menimbulkan risiko. Selain itu, manfaat sistem traceability dapat mengurangi risiko yang berbahaya dalam proses produksi dan dapat dengan cepat meresponnya, mengendalikan potensi yang berisiko tinggi agar dapat mencegah kejadian yang tidak terduga serta memperkuat pengendalian pada potensi yang berisiko (Koreshkov, 2009). Li, (2009) menggunakan sistem traceability untuk memprediksikan risiko pada product recall. Begitu juga dengan Bevilacqua et al. (2009) menyatakan bahwa produsen yang menyimpan bahan baku dan proses produksi memiliki potensi risiko pada pencampuran atau kehilangan identitas rantai produksi yang mungkin terjadi dapat diatasi dengan sistem traceability.

Disamping itu tujuan sistem traceability dapat meningkatkan transparansi dalam rantai supplai, mengurangi risiko klaim, meningkatkan efisiensi (Miranda et al, 2003) dan manajemen risiko (Engelseth, 2009; Vanany, 2012). Dengan demikian diketahui bahwa traceability dapat memberikan informasi yang cepat untuk mencegah, menemukan potensi risiko dan mengurangi risiko pada proses rantai pasok makanan. Oleh karena itu penelitian ini bertujuan melakukan penaksiran risiko yang terjadi pada rantai pasok minuman sari apel berdasarkan informasi sistem traceability. Untuk mengetahui proses yang terkait dengan aktivitas traceability terlebih dahulu merancang proses bisnis yang mana dalam penelitian ini menggunakan metode SCOR (Supply Chain Operation Reference). Sedangkan penilaian risiko rantai pasok makanan dalam mendapatkan level risiko menggunakan teknik FMEA (Failure Mode and Effects Analysis). Upaya yang dilakukan dalam mengetahui risiko yang dapat ditangani dengan sistem traceability menggunakan metode House of Risk (HOR) oleh PujawaN, et al, (2009) yang merupakan pengembangan metode Quality Function Deployment.

\section{METODE PENELITIAN}

Tahapan yang perlu dilakukan dalam penelitian sabagai berikut; aktivitas rantai pasok dalam sistem traceability, mengidentifikasi risiko yang terjadi berdasarkan informasi sistem traceability dilanjutkan dengan metode HOR dalam mengetahui potensi risiko yang bisa di tanggulangi dengan sistem traceability.

Aktivitas rantai pasok yang terkait dalam sistem traceability

Penentuan aktivitas yang terkait traceability untuk area proses bisnis disetiap pelaku dari rantai pasok dilakukan setelah 
mengetahui area proses bisnis untuk setiap pelaku dari rantai pasok. SCOR digunakan untuk menggolongkan aktivitas yang terjadi dari supplier sampai customer sesuai proses yang terdapat pada model SCOR dari tiap aktivitas pada identifikasi untuk membangun sistem traceability.

\section{Identifikasi Risiko Berbasis Traceability}

Proses identifikasi risiko merupakan tahapan penting untuk mengidentifikasi kejadian risiko (risk event) terhadap proses bisnis yang sudah dibuat. Dengan melakukan pemetaan aktivitas rantai pasok makanan berdasarkan SCOR (plan, source, make, delivery dan return yang disebut bisnis area dalam penelitian ini). Hal ini untuk mengetahui risiko dan penyebab dari risiko yang terjadi, penyebab risiko dalam penelitian ini disebut dengan risk agent. Proses identifikasi risiko dan penyebab risiko dilakukan dengan cara literature review, mengetahui kondisi perusahaan, proses bisnis perusahaan, data historis perusahaan, dan stakeholder perusahaan. Mekanisme yang digunakan dalam tahap identifikasi risiko adalah survey, melakukan Focus Group Discussion (FGD) dan wawancara kepada para stakeholder. Hasil yang didapatkan dari identifikasi risiko sebagai inputan dalam FMEA. Dalam penelitian ini hanya membahas jenis risiko yang bisa ditangani dengan traceability.

\section{Analisis Penilaian Risiko}

Penilaian risiko didapatkan dengan cara memberikan kuisioner kepada pihak perusahaan yang berwenang dan mengerti akan aktivitas rantai pasok perusahaan secara keseluruhan yaitu PPIC Manager dan General Manager. Selain kuisioner atau wawancara, analisis dan penilaian risiko juga bisa berdasarkan data historis yang ada. Proses identifikasi potential effect penting untuk dilakukan karena akan mempengarui penilaian terhadap risiko, membantu menentukan tingkat dampak (severity), dari suatu kejadian risiko atau seberapa besar gangguan yang ditimbulkan oleh suatu kejadian risiko terhadap proses bisnis perusahaan. Nilai ini akan berpengaruh terhadap penentuan prioritas risiko. Sementara proses identifikasi penyebab risiko (risk causes) dilakuan dengan mengidentifikasi akar permasalahan dari masing-masing risiko yang telah teridentifikasi sebelumnya secara menyeluruh. Proses risk causes untuk menentukan nilai occurance serta korelasinya (correlation) dengan suatu kejadian risiko, yang mana langkah berikutnya dilakukan perhitungan aggregate risk potentials (ARP) dengan cara melakukan perkalian bobot dari severity, occurance dan nilai korelasi dari matriks HOR. Penilaian severity dan occurance menggunakan dengan konsep FMEA (Failure Modes Effect Analysis) dengan skala penilaian 1-10. Hasil perhitungan ini akan digunakan untuk melakukan penaksiran risiko pada model House of Risk (HOR).

\section{Evaluasi Risiko}

Pada tahap ini menggunakan analisis pareto untuk menentukan tingkat prioritas penyebab risiko dengan mengetahui nilai ARP (aggregate risk potentials) dari tiap-tiap penyebab risiko yang diurutkan dari penyebab risiko dengan nilai terbesar hingga penyebab risiko dengan nilai terkecil yang dapat dilihat dari diagram batang. Sedangkan akumulasi nilai dari masing-masing penyebab risiko mulai dari penyebab risiko dengan nilai terbesar sampai dengan nilai terkecil yang ditunjukkan oleh diagram garis yang ada. Sehingga diketahui penyebab risiko mana saja yang masuk kategori risiko tinggi, risiko sedang dan risiko rendah. Penyebab risiko yang termasuk ke dalam risiko tingkat tinggi dengan nilai kumulatif aggregate risk potentials (ARP) sebesar $80 \%$ dari total nilai kumulatif ARP seluruh penyebab risiko. Hal ini mengadopsi dari prinsip 80:20 pareto, yaitu melakukan penanganan terhadap sebagian kecil risiko yang menghasilkan sebagian besar dampak dari keseluruhan dampak yang ditimbulkan oleh keseluruhan risiko. Teknik yang digunakan pada tahap ini 
menggunakan QFD, yang dilakukan pada fase matriks rumah kualitas yaitu matriks HOQ (House Of Quality), dengan merubah fungsi $\mathrm{HOQ}$ dari tool perencanaan produk menjadi tool analisa risiko menjadi HOR (House of Risk). HOR digunakan untuk menentukan prioritas penyebab risiko yang terjadi agar mendapatkan mitigasi sebagai pencegahan di kemudian hari (Pujawan dan Geraldin, 2009).

\section{HASIL DAN PEMBAHASAN}

\section{Risiko Berdasarkan Traceability}

Risiko yang bisa direduksi dengan traceability merupakan suatu aktivitas yang dapat diidentifikasi dalam memberikan informasi dan dapat dilakukan pelusuran apabila terdapat suatu kejadian pada rantai pasok makanan dengan melihat informasi yang diberikan pada masing-masing aktivitas baik unit aliran produk maupun bahan baku. Hal ini bertujuan untuk memberikan informasi data produk dan material dari setiap proses apabila terjadi suatu kejadian yang berkaitan dengan produk dan keamanan pangan. Jenis risiko minuman sari apel terdapat 24 jenis sedangkan risiko yang bisa ditangani dengan traceability sejumlah 13 jenis. Dalam penelitian hanya membahas risiko yang bisa ditangani dengan traceability. Tabel 1 merupakan risiko yang telah identifikasi sesuai dengan informasi traceability.

Tabel 1. Risiko rantai pasok berdasarkan traceability

\begin{tabular}{|c|c|c|}
\hline $\begin{array}{l}\text { Area } \\
\text { proses } \\
\text { bisnis }\end{array}$ & Aktivitas & Risk Event \\
\hline Plan & $\begin{array}{l}\text { Pemeriksaan level stok sari buah } \\
\text { dan level stok produk minuman sari } \\
\text { buah }\end{array}$ & $\begin{array}{l}\text { Jumlah bahan baku dan produk yang ada digudang } \\
\text { tidak sesuai dengan yang ada di database } \\
\text { perusahaan } \\
\text { Kekurangan barang dan bahan baku digudang }\end{array}$ \\
\hline \multirow[t]{3}{*}{ Source } & Penerimaan material dari pemasok & Keterlambatan penerimaan bahan baku \\
\hline & $\begin{array}{l}\text { Pembongkaran dan Inspeksi bahan } \\
\text { baku }\end{array}$ & Ketidak sesuaian barang yang dipesan \\
\hline & Penyimpanan bahan baku & Material busuk \\
\hline \multirow[t]{4}{*}{ Make } & Penyimpanan sari buah di gudang & Sari buah rusak digudang \\
\hline & $\begin{array}{l}\text { Aktivitas produksi } \\
\text { Mengeluarkan sari buah dalam } \\
\text { gudang untuk memulai aktivitas } \\
\text { proses }\end{array}$ & $\begin{array}{l}\text { Tercampurnya sari apel dengan benda lain } \\
\text { Kesalahan dalam pengambilan sari buah yang } \\
\text { tidak bersifat FIFO }\end{array}$ \\
\hline & $\begin{array}{l}\text { Inspeksi kualitas produk minuman } \\
\text { sari buah }\end{array}$ & Kualitas produk tidak sesuai \\
\hline & Labeling produk jadi & Kesalahan memberikan identitas \\
\hline \multirow[t]{3}{*}{ Deliver } & $\begin{array}{l}\text { Penyimpanan produk minuman sari } \\
\text { apel di gudang }\end{array}$ & Produk rusak digudang \\
\hline & Persiapan pengiriman produk jadi & Kesalahan pengangkutan produk \\
\hline & Pengiriman produk ke distributor & Produk cacat dalam perjalanan \\
\hline
\end{tabular}


Risiko yang bisa direduksi dengan traceability sejumlah 13 kejadian risiko, sedangkan alasan mengapa risiko tersebut dapat direduksi dengan traceability akan dijelaskan sebagai berikut: a)Kekurangan barang dan bahan baku digudang salah satu risiko traceability karena dengan traceability dapat diketahui letak ketidak sesuainnya antara pemasaran, produksi dan pengadaan barang. c)Keterlambatan penerimaan material merupakan risiko traceability karena mampu ditelusuri penyebab keterlambatannya. d) Ketidak sesuaian barang yang dipesan dapat diatasi dengan membuat standar operation procedure pengadaan barang sampai barang ditrima. e) Material busuk merupakan risiko yang dapat mengakibatkan penundaan terhadap pemenuhan permintaan konsumen, risiko ini dapat ditelusuri dengan cara siapa tenaga kerja yang melakukan penerimaan ketika barang datang, bagaimana kondisi awal saat penerimaan dan nama supplier, tanggal masuk. f) Sari buah rusak digudang adalah risiko yang bisa dikendalikan dengan traceability dengan cara melakukan pengkodean area gudang untuk memastikan proses FIFO serta memperhatikan prosedur penyimpanan misalnya suhu ruangan gudang, peletakkan galon sari buah. g) Tercampurnya sari apel dengan benda lain, dengan traceability dapat dilakukan penelusuran aktivitas produks terhadap bagaimana persiapan proses produksi, siapa operatornya, kebersihan peralatanya. h) Kesalahan pengangkutan produk dapat ditelusuri dengan penempatan produk. i) Kesalahan dalam pengambilan galon sari buah yang tidak bersifat FIFO, risiko ini dapat ditelusuri dengan pemberian kode yaitu kapan di buah diperas, penempatannya. j)Kualitas produk tidak sesuai merupakan risiko traceability karena dapat ditelusuri dengan mengetahui komposisi bahan baku, zat pewarna, dll serta cara memproduksinya. k) Kesalahan memberikan identitas dengan cara memperjelas pengkodeaannya dan training pengkodeaan. 1) Produk rusak digudang dapat ditelusuri dengan kapasitas gudang, barang yang ada digudang, bagaimana proses peletakkannya, proses pengambilannya. $\mathrm{m}$ ) Produk cacat dalam perjalanan, hal yang perlu dilakukan dalam risiko ini yaitu mengidentifikasi nama orang yang mendistribusikan, jenis kendaraan, kapasitas kendaraan serta prosedur pengangkutan.

Risiko yang bisa direduksi dengan traceability merupakan suatu kejadian risiko yang dapat ditelusuri dengan cara: 1) mengidentifikasi dan memberikan variabel produk pada setiap lokasi, 2) mengambil dan merekam data traceability, 3) manajemen yang terhubung dan 4) mengkomunikasikan data traceability (ECR, 2004). Adapun risiko yang dapat direduksi dengan traceability selengkapnya pada Tabel 2.

Tabel 2 Jenis risiko yang bisa di reduksi traceability

\begin{tabular}{clc}
\hline No & \multicolumn{1}{c}{ Kejadian Risiko } & Bobot \\
\hline 1 & Jumlah bahan baku dan produk yang ada digudang tidak sesuai dengan & 35 \\
& yang ada di database perusahaan & \\
2 & Kekurangan barang dan bahan baku digudang & 140 \\
3 & Keterlambatan penerimaan bahan baku & 78 \\
4 & Ketidak sesuaian barang yang dipesan & 36 \\
5 & Material busuk & 72 \\
6 & Sari buah rusak digudang & 49 \\
7 & Sari apel tercampur dengan benda lainnya & 42 \\
8 & Kesalahan dalam pengambilan galon sari buah yang tidak bersifat FIFO & 65 \\
9 & Kualitas produk tidak sesuai & 60 \\
10 & Kesalahan memberikan identitas & 15 \\
11 & Produk rusak digudang & 52 \\
12 & Kesalahan pengangkutan produk & 48 \\
13 & Produk cacat dalam perjalanan & 36 \\
\hline
\end{tabular}


Tabel 3 Penyebab risiko yang mengakibatkan kejadian risiko

\begin{tabular}{lll}
\hline \multicolumn{1}{c}{ Penyebab risiko } & \multicolumn{1}{c}{ Kejadian risiko } \\
\hline Tidak ada prosedur kerja sales & Kekurangan barang dan bahan baku di gudang \\
Tidak memperhatikan standar kualitas & Ketidak sesuaian barang yang di pesan \\
Tidak ada prosedur penyimpanan & Material busuk \\
Mengabaikan standar kualitas penerimaan bahan baku & & 9 \\
Kurang memperhatikan prosedur penyimpanan & Sari buah rusak di gudang \\
Penandaan yang kurang jelas & Kesalahan pengambilan sari buah tidak bersifat FIFO \\
Prosedur pengambilan & \\
Inspeksi dilakukan di akhir produk & Sari apel tercampur dengan benda lain \\
Kesalahan komposisi bahan baku dan proses produksi & Kualitas produk tidak sesuai \\
Kesalahan letak penyimpanan & Kesalahan pengangkutan produk \\
Prosedur kerja kurang jelas & Produk rusak digudang \\
Kelebihan persediaan & & 9 \\
\hline
\end{tabular}

Terdapat 1 risiko ekstrime dengan bobot 140 yaitu risiko terjadinya kekurangan barang dan bahan baku digudang. Sedangkan risiko yang bobotnya berkisar 51- 100 sebanyak lima Risiko yang berkatagori rendah dengan bobot lebih kecil 50 sejumlah tujuh. Risiko tinggi cenderung peluang terjadinya sering sedangkan risiko tengah peluang terjadinya rata-rata dan risiko rendah frekuensi kejadiannya jarang terjadi.

Analisa Penyebab
Traceability
Penyebab risiko yang terjadi tidak
semuanya dapat ditangani dengan
traceability, dari dua puluh empat penyebab risiko ada 13 penyebab risiko yang dapat ditangani dengan traceability yaitu: kesalahan letak penyimpanan, kurang memperhatikan prosedur penyimpanan produk, kesalahan komposisi material, kelebiha persediaan, pemberian tanda yang kurang jelas, kesalahan penyimpanan, tidak ada prosedur kerja yang jelas, inspeksi dilakukan di akhir produksi, mengabaikan standar kualitas penerimaan bahan baku. Risiko yang terjadi $70 \%$ risiko ini disebabkan oleh penyebab risiko yang bisa dimitigasi dengan traceability. Terdapat dua puluh empat penyebab risiko yang mana $50 \%$ dapat ditangani dengan traceability.

\section{Penyebab Risiko dan Korelasi Kejadian Risiko}

Pada tahap ini dilakukan pemetaan kejadian risiko yang ditimbulkan oleh penyebab risiko yang dapat diatasi dengan traceability. Ada delapan penyebab risiko dapat diatasi dengan traceability dan dilakukan penilaian berdasarkan peluang kemunculan penyebab risiko (occurrence) beserta nilai korelasi antara kejadian risiko dan penyebab risiko. Dalam mengidentifikasi nilai peluang kemunculan penyebab risiko (occurrence), digunakan skala likert 1-10 dengan kriteria deskripitif tertentu. Sedangkan dalam mengidentifikasi nilai korelasi penyebab risiko dan kejadian risiko menggunakan kriteria korelasi kuat, sedang, lemah, hal ini menunjukkan seberapa kuat penyebab risiko tersebut memunculkan kejadian risiko. Lebih jelasnya dituangkan dalam matrik house of risk yang terdapat pada Gambar 1. Risk Priority Number terbesar 504 yaitu tidak adanya prosedur kerja sales yang jelas, dapat diketahui bahwa kurangnya prosedur yang jelas menyebabkan kekurangan barang dan bahan baku digudang serta kesalahan pengangkutan produk hal ini disebabkan tidak adanya petunjuk atau prosedur dalam melakukan aktivitas di perusahaan secara detail dan jelas bagi tenaga kerja. Selain itu risiko lainnya adalah kesalahan dalam pengambilan sari buah yang tidak bersifat FIFO. Penyebab risiko yang bisa ditangani dengan traceability dapat dilihat pada Tabel 3. 


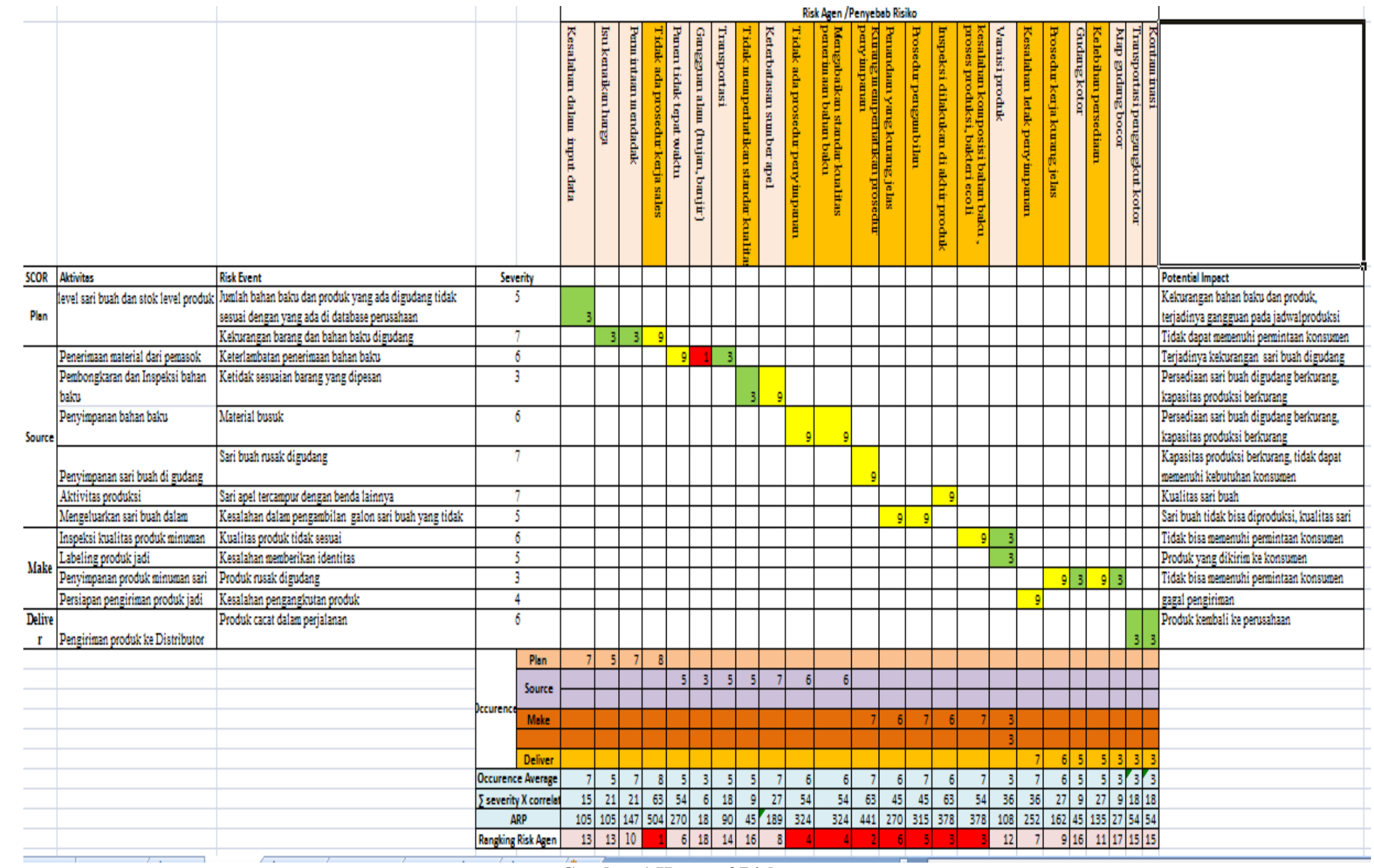

Gambar 1 House of Risk 
Tabel 4 merupakan penyebab risiko yang bisa ditangani dengan traceability, adapun analisisnya diuraikan sebagai berikut: a) Kesalahan penyimpanan dapat membuat kerusakan bahan baku apel yang disebabkan kesalahan pembongkaran bahan baku digudang yang mengakibatkan buah rusak (luka) dan lamanya penyimpanan juga berdampak terhadap kwalitas dari bahan baku. b) Penyebab risiko penerimaan material dapat mengakibatkan bahan baku busuk hal ini dikarenakan kurangnya kontrol ketika barang penerimaan material. Penyabab risiko ini dapat ditelusuri dengan melihat siapa yang bertugas pada waktu penerimaan barang, berasal dari suplier mana, kapan penerimaanya, bagaimana kondisi bahan baku pada waktu datang. c) Kurang memperhatikan prosedur penyimpanan merupakan penyebab risiko yang bisa ditelusuri apabila terjadinya risiko. Penelusuran ini dengan mengecek berapa suhu ruangannya, bagaimana penempatan bahan baku sari apel, bagaimana pengambilan barang dari gudang. e) Kesalahan letak penyimpanan, berdampak terhadap kesalahan pengangkutan produk. Penyebab ini bisa ditelusuri dengan menelaksanakan standar operation procedure. d) Pemberian tanda kurang jelas dapat dikatagorikan penyebab risiko yang mampu diatasi dengan traceability karena dapat diatasi dengan memberikan label dan keterangan yang mudah dipahami. f) Kesalahan komposisi material dalam proses, peran traceability pada penyebab risiko ini dengan melakukan pendokumentasian, mencatat, merekam terhadap aktivitas produksi. g) Kelebihan persediaan dapat dikatakan penyebab risiko traceability karena dapat dilakukan dengan menerapkan SOP produksi. h) Prosedur kerja kurang jelas merupakan penyebab risiko yang menimbulkan beberapa risiko terjadi.

\section{Risk Priority Index}

Penentuan urutan penyebab risiko dilakukan dengan melihat tingkat dampak (severity), tingkat terjadinya risiko (occurance) serta tingkat korelasi antara penyebab risiko dengan kejadian risiko yang ditimbulkan. Tingkat Nilai indeks prioritas risiko digunakan untuk mengetahui penyebab risiko yang akan dilakukan penanganan dan perancangan mitigasi risiko yang berbasis traceability. Dari perhitungan nilai indeks prioritas risiko didapatkan urutan risiko yang memiliki prioritas yang terbesar sampai yang terkecil selengkapnya dapat dilihat pada Tabel 4 dan Gambar 1. Tidak semua penyebab risiko dilakukan mitigasi dengan sistem traceability akan tetapi mitigasi yang dilakukan dengan strategi lainnya.

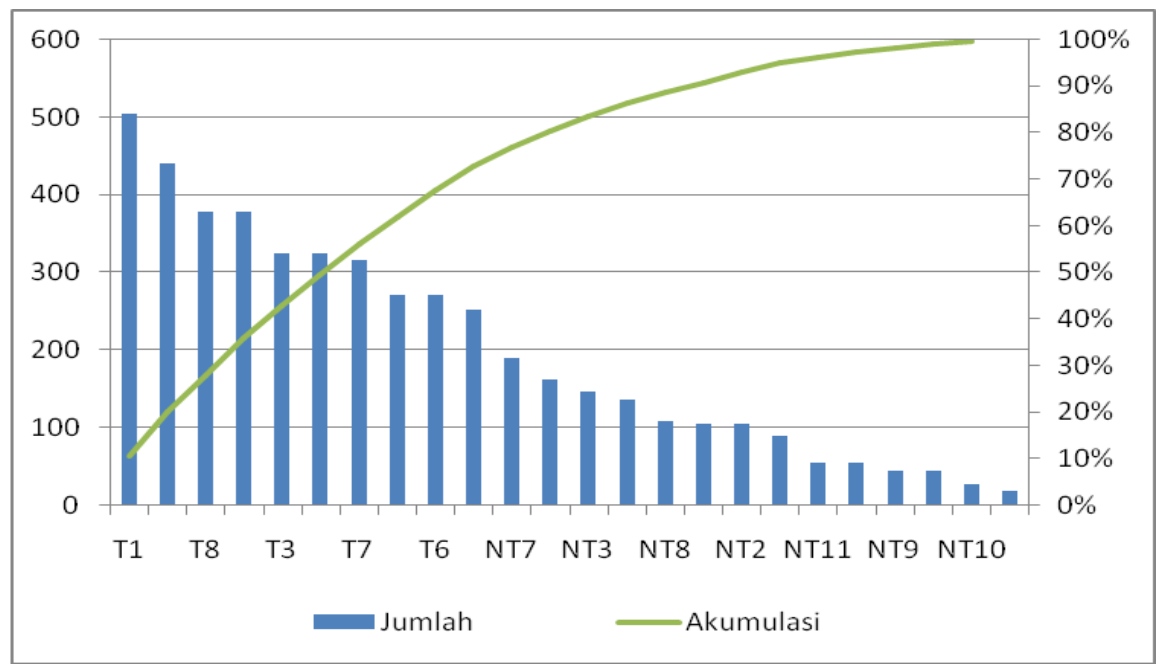

Gambar 2 Diagram pareto dari penyebab risiko 
Tabel 4 Hasil Perhitungan Aggregat Risk Potential

\begin{tabular}{clcc}
\hline Kode & \multicolumn{1}{c}{ Penyebab Risiko } & ARP & Rangking \\
\hline T1 & Tidak ada prosedur kerja sales & 504 & 1 \\
T5 & Kurang memperhatikan prosedur penyimpanan & 441 & 2 \\
T8 & Inspeksi dilakukan di akhiri proses & 378 & 3 \\
T9 & Kesalahan komposisi bahan baku & 378 & 3 \\
T3 & Tidak ada prosedur penyimpanan & 324 & 4 \\
T4 & Mengabaikan standar kualitas penerimaan bahan baku & 324 & 4 \\
T7 & Prosedur pengambilan & 315 & 5 \\
NT4 & Panen tidak tepat waktu & 270 & 6 \\
T6 & Penandaan yang kurang jelas & 270 & 6 \\
T10 & Kesalahan letak penyimpanan & 252 & 7 \\
NT7 & Keterbatasan sumber apel & 189 & 8 \\
T11 & Prosedur pengambilan & 162 & 9 \\
NT3 & Permintaan mendadak dari konsumen & 147 & 10 \\
T12 & Kelebihan persediaan & 135 & 11 \\
NT8 & Variasi produk & 108 & 12 \\
NT1 & Kesalahan dalam menginput data & 105 & 13 \\
NT2 & Isu kenaikan harga & 105 & 13 \\
NT6 & Transportasi & 90 & 14 \\
NT11 & Transportasi pengangkutan kotor & 54 & 15 \\
NT12 & Kontaminasi & 54 & 16 \\
NT9 & Gudang bocor & 45 & 17 \\
T2 & Tidak memperhatikan standar kualitas & 45 & 17 \\
NT10 & atap gudang bocor & 27 & 18 \\
NT5 & Hujan,banjir & 18 & 19 \\
\hline
\end{tabular}

Perhitungan risk priority index didapatkan urutan penyebab risiko yang memiliki nilai prioritas yang terbesar sampai yang terkecil. Penyebab risiko yang mempunyai nilai bobot besar merupakan penyebab risiko yang bisa dimitigasi dengan traceability. Hal ini berkaitan dengan jenis risiko yang terjadi berasal dari aktivitas traceability sesuai dengan hasil pemetaan aktivitas traceability. simbol yang digunakan pada Tabel 4 NT mempunyai arti bahwa penyebab risiko adalah non traceability sedangkan simbol $\mathrm{T}$ yaitu penyebab risiko yang bisa ditangani dengan traceability. Selengkapnya dapat dilihat pada Tabel 5 dan Gambar 2

\section{Pemetaan Penyebab Risiko}

Pemetaan penyebab risiko dilakukan untuk mendapatkan level risiko. Pemetaan risiko ini menggunakan range yang berdasarkan nilai ARP, yang menunjukkan tingak penyebab risiko sesuai dengan nilai ARP yang diperoleh. Nilai ARP tertinggi sebesar 504 dan terendah sebesar 18, nilai tengahnya 168 sehingga dalam pemetaan penyebab risiko dibagi menjadi tiga yaitu tinggi, sedang dan rendah. Terdapa tiga peyebab risiko yang tinggi nilainya lebih dari 336, penyebab risiko sedang sebanyak tujuh dan penyebab risiko rendah sejumlah tiga belas. Tabel 5 menunjukkan penggolongan jenis risiko berdasarkan nilai RPN. 
Tabel 5 Penggolongan Penyebab Risiko

\begin{tabular}{llc}
\hline \multicolumn{1}{c}{ Range Nilai } & \multicolumn{1}{c}{ Penyebab Risiko } & ARP \\
\hline Tinggi & Tidak ada prosedur kerja sales & 504 \\
ARP $\geq 336$ & Kurang memperhatikan prosedur penyimpanan & 441 \\
& Inspeksi dilakukan di akhiri proses & 378 \\
Menengah & Kesalahan komposisi bahan baku & 378 \\
$168<$ ARP $\leq 335$ & Tidak ada prosedur penyimpanan & 324 \\
& & \\
& mengabaikan standar kualitas penerimaan bahan baku & 324 \\
& prosedur pengambilan & 315 \\
& Panen tidak tepat waktu & 270 \\
& Penandaan yang kurang jelas & 270 \\
& & \\
& Kesalahan letak penyimpanan & 252 \\
KRP $\leq 167$ & Keterbatasan sumber apel & 189 \\
& prosedur pengambilan & 162 \\
& Permintaan mendadak dari konsumen & 147 \\
& kelebihan persediaan & 135 \\
& Variasi produk & 108 \\
& Kesalahan dalam menginput data & 105 \\
& Isu kenaikan harga & 105 \\
& Transportasi & 90 \\
& transportasi pengangkutan kotor & 54 \\
Kontaminasi & 54 \\
Gudang bocor & 45 \\
Tidak memperhatikan standar kualitas & 45 \\
& atap gudang bocor & 27 \\
Hujan,banjir & 18 \\
\hline
\end{tabular}

Risiko yang mendominasi berdasarkan nilai RPN merupakan penyebab risiko yang dapat ditangani dengan traceability sebesar $75 \%$. Hal ini menunjukkan bahwa peran traceability pada rantai pasok makanan dapat mereduksi risiko yang terjadi.

\section{Pemetaan Penyebab Risiko Berdasarkan Proses Bisnis}

Pemetaan penyebab risiko berdasarkan proses bisnis bertujuan untuk mengetahui penyebab risiko yang sering terjadi pada area proses bisnis. Area proses bisnis dibagi menjadi: plan, source, make, deliver. Penyebab risiko yang bisa ditangani dengan traceability sebanyak $75 \%$ dari semua penyebab risiko yang terjadi. Berdasarkan hasil pemetaan penyebab risiko berdasarkan SCOR menunjukkan bahwa make menghasilkan nilai yang paling tinggi sebesar 1890 atau $40 \%$ penyebab risiko ada pada proses make. Selengkapnya dapat dilihat pada Tabel 6 
Tabel 6 Pemetaan Risiko Berdasarkan Proses Bisnis

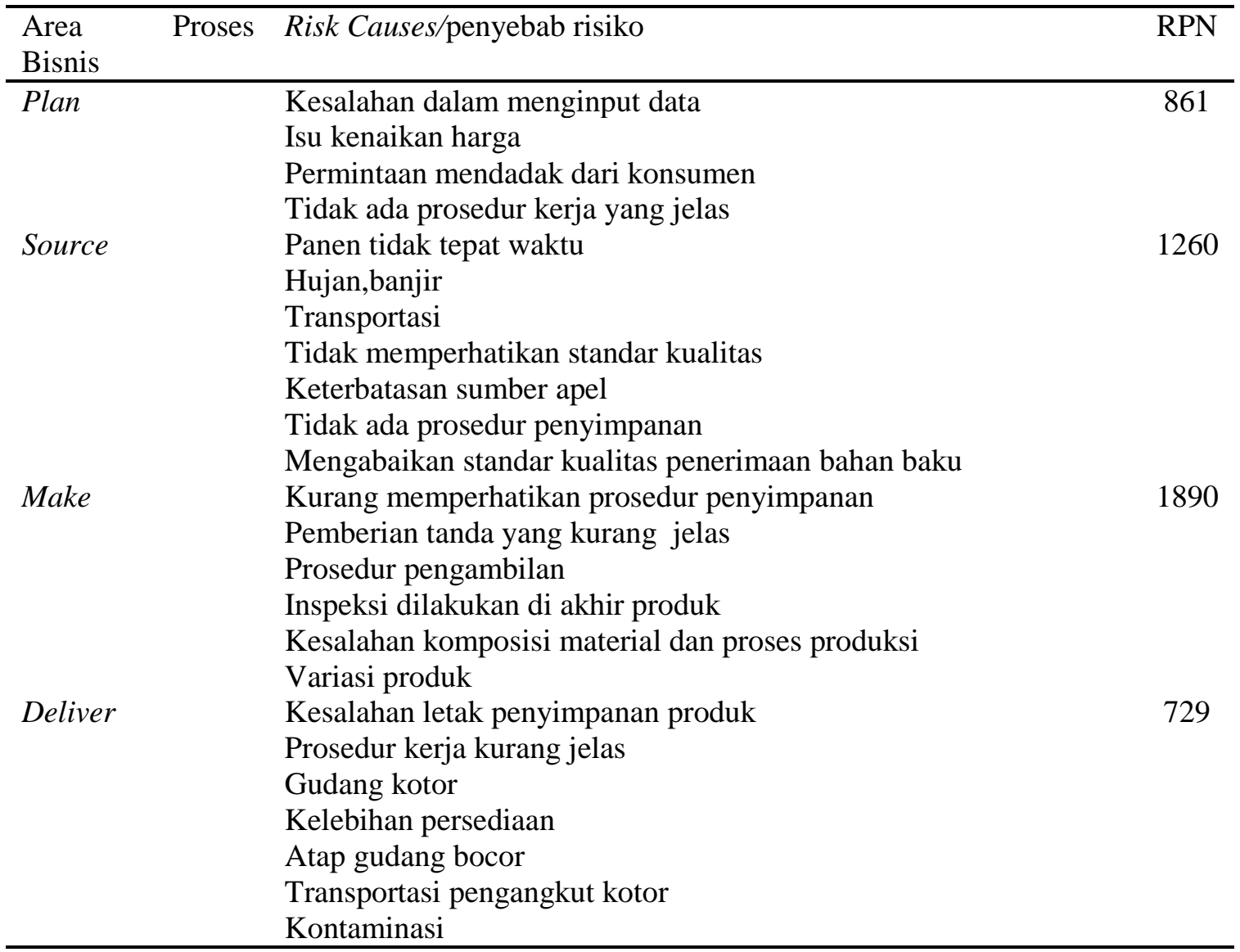

Penyebab risiko yang kedua terdapat pada source sebesar 27\% . Make merupakan proses bisnis yang melakukan aktivitas proses produksi dalam merubah buah apel mejadi minuman sari apel. Source sebagai penanganan bahan baku mulai penerimaan bahan baku sampai penyimpanan di gudang. Hal ini menunjukkan keterkaitan antara penanganan bahan baku dan proses produksi pada produk makanan, sehingga risiko yang sering muncul pada produk sari apel terdapat pada source dan make, dibandingkan dengan yang lainnya. Oleh karena itu penanggulangan risiko pada proses produksi dan penanganan bahan baku sangat penting sekali, apabila ini tidak ditanggulangi risiko yang biasanya terjadi kemungkinan akan terjadi di kemudian hari. Sedangkan aktivitas pengiriman risiko yang sering terjadi pada kesalahan dalam mengakut produk. Penyebab risiko yang sering terjadi pada dieiver yaitu kesalahan letak penyimpanan dan tidak ada prosedur yang jelas. Penyebab risiko ini $15 \%$ pada deliver yang sering terjadi. Selanjutnya pada penyebab risiko yang terjadi pada proses bisnis plan sebesar 18\% dikarenakan tidak ada prosedur yang jelas dalam menagani perencanaan mulai kebutuhan produksi, kebutuhan bahan baku dan lain-lain.

\section{KESIMPULAN}

Risiko rantai pasok minuman sari apel yang dapati ditangani dengan tracebility sejumlah 13 jenis risiko, Terdapat 1 risiko ekstrime dengan bobot 140 yaitu risiko terjadinya kekurangan barang dan bahan baku digudang. Sedangkan risiko sedang dengan bobotnya berkisar 51- 100 sebanyak lima. Risiko yang berkatagori rendah dengan bobot lebih kecil 50 sejumlah tujuh. Penyebab risiko yang tinggi sejumlah tiga yaitu; tidak ada prosedur yang jelas, kurang 
memperhatikan prosedur penyimpanan, inspeksi dilakukan di akhir proses dan kesalahan komposisi bahan baku, dengan demikian risiko yang sering terjadi terdapat pada aktivitas proses produksi dan penganan bahan baku mulai penerimaan sampai penyimpanan di gudang. Sedangkan penyebab risiko yang bisa ditangani dengan traceability sebanyak $75 \%$ dari semua penyebab risiko yang terjadi. Hal ini menunjukkan bahwa peran traceability pada rantai pasok makanan dapat mereduksi risiko yang terjadi. Dengan traceability dapat memberikan informasi yang cepat untuk mencegah, menemukan potensi risiko dan mengurangi risiko pada proses rantai pasok makanan

\section{DAFTAR PUSTAKA}

1. Engelseth, P., Food product traceability and supply network integration, The Journal of Business and Industrial Marketing, 2009, 24 (5-6), 421-430

2. ERC., ERC - using traceability in the supply chain to meet consumer safety expectations, available at: www.ecrnet.org/04 publications/blue books/pub 2004 traceability blue book. $P d f$, 2004, (di akses pada 21 November 2011).

3. Juttner, U., Peck, H., \& Christopher, M., Supply chain risk management: Outlining an Agenda for future research. International Journal of Logistics: Research and Applications, 2003, 6(4), 197-210
4. Kher, S., Frewer, L.J., De Jonge, J. and Wentholt, M.T.A., Experts'perspectives on the implementation of traceability in Europe, British Food Journal, 2010, Vol. 112 No. 3, 2010, pp. 261-274

5. Liu., Peraturan standar dan sertifikasi ekspor produk pertanian, Embun Pagi Grafika, 2007, Jakarta

6. Miranda P. M. Meuwissen, Annet G. J. V., Henk Hogeveen., and Ruud B. M., Traceability and Certification in Meat Supply Chains, Journal of Agribusiness 21, 2003, :167S181.

7. Pujawan, I Nyoman, Geraldin., House of Risk: A model for proactive supply chain risk management, Business Process Management Jounal, 2009, Vol 15, No 6.

8. Sinha, P.R., Whitman, L.E. and Malzahn, D., Methodology to mitigate supplier risk in an aerospace supply chain, Supply Chain Management: An International Journal, 2004, Vol. 9 No. 2, pp. 154-68.

9. Svensson, G., A conceptual framework for the analysis of vulnerability in supply chains, International Journal of Physical Distribution \& Logistics Management, 2000, Vol. 30 No. 9, pp. 731-49.

10.Vanany,I., Pujawan,I.N.,Setyaningrum, P.,Iryaning, H., Business Process Approach For Traceability System, International Conference on Intelligent Manufacturing and Logostics Systems, 2012 